\title{
Dopamine and Serotonin Receptor Binding and Antipsychotic Efficacy
}

\author{
Neil M Richtand*, ${ }^{1,2}$, Jeffrey A Welge ${ }^{2,3}$, Aaron D Logue ${ }^{1,2}$, Paul E Keck Jr ${ }^{1,2}$, Stephen M Strakowski ${ }^{2}$ and \\ Robert K McNamara ${ }^{2}$
}

'Psychiatry Service, Cincinnati Veterans Affairs Medical Center, Cincinnati, OH, USA; ${ }^{2}$ Department of Psychiatry, University of Cincinnati College of Medicine, Cincinnati, OH, USA; ${ }^{3}$ Center for Biostatistical Services, University of Cincinnati College of Medicine, Cincinnati, OH, USA

\begin{abstract}
The relationship between clinically effective antipsychotic drug dosage and binding affinity to cloned dopamine (DA) and serotonin receptor subtypes was analyzed in an effort to elucidate the contribution of individual receptor subtypes to medication response. Clinically effective dose and binding affinity to $D_{2}$ DA receptor were modestly correlated for typical antipsychotic medications $(r=0.54$, $p=0.046)$, but surprisingly were not correlated for atypical antipsychotics $(r=0.4 \mathrm{I}, p=0.3 \mathrm{I})$. For typical antipsychotics, a more robust inverse relationship was observed between medication dose and $5-\mathrm{HT}_{2} \mathrm{C}$ affinity $(r=-0.68, p=0.02 \mathrm{I})$. The strongest correlation for typical antipsychotics was observed between drug dosage and $5-\mathrm{HT}_{2} \mathrm{C} / \mathrm{D}_{2}$ binding affinity ratio $(r=-0.81, p=0.003)$. For atypical antipsychotics, no significant correlations were identified between medication dosage and 5-HT $2 \mathrm{C}, 5-\mathrm{HT}_{2 \mathrm{~A}}, 5-\mathrm{HT}_{2} \mathrm{C} / \mathrm{D}_{2}$, or $5-\mathrm{HT}_{2 \mathrm{~A}} / \mathrm{D}_{2}$ receptor-binding affinities. In contrast, atypical antipsychotic medication dosage was highly correlated with the ratios of $\mathrm{D}_{2}\left(5-\mathrm{HT}_{2 \mathrm{~A}} /\right.$ $\left.5-\mathrm{HT}_{\mid \mathrm{A}}\right)(r=0.80, p=0.03 \mathrm{I})$, and $\mathrm{D}_{2}\left(5-\mathrm{HT}_{2} \mathrm{C} / 5-\mathrm{HT} / \mathrm{A}\right)(r=0.78, p=0.038)$ binding affinities. These observations demonstrate an interaction between $\mathrm{D}_{2}$ and $5-\mathrm{HT}_{2}$ receptor effects contributing to positive symptom response for typical antipsychotic medications, suggesting that signaling through $5-\mathrm{HT}_{2}$ receptors interacts with and improves antipsychotic effects achieved via $\mathrm{D}_{2}$ receptor blockade. This analysis also demonstrates that, in contrast to typical antipsychotics, therapeutic effects of atypical antipsychotic medications are determined by opposing interactions among three different domains: $(I)$ increasing $D_{2}$ DA receptor-binding affinity enhances antipsychotic potency. (2) Increasing $5-\mathrm{HT}_{2}$ and $5-\mathrm{HT}_{2 A}$ receptor-binding affinities also facilitate antipsychotic efficacy. (3) Increasing $5-\mathrm{HT}_{\text {IA }}$ receptor-binding affinity, in contrast, reduces antipsychotic efficacy.

Neuropsychopharmacology (2007) 32, I7I5-1726; doi:I0.1038/sj.npp. I30।305; published online 24 January 2007
\end{abstract}

Keywords: dopamine; serotonin; schizophrenia; psychosis; neuroleptic; antipsychotic

\section{INTRODUCTION}

Thirty years after the description of a direct linear correlation between dopamine (DA) $\mathrm{D}_{2}$ receptor-binding affinities and antipsychotic drug potencies for ameliorating psychosis (Seeman et al, 1976; Creese et al, 1976), this association remains an important cornerstone of current hypotheses of both the etiology and treatment of psychotic disorders (Emilien et al, 1999; Seeman, 2002; Seeman and Tallerico, 1998). However, over the past quarter century significant advances have been made in expanding our understanding of receptor-binding affinities and clinically effective drug dosages for a steadily expanding list of

\footnotetext{
*Correspondence: Dr NM Richtand, Department of Psychiatry, University of Cincinnati, College of Medicine, 23I Albert Sabin Way, ML0559, Cincinnati, Ohio 45267-0559, USA, Tel: + I 5135586657 , Fax: + I 513558 0042, E-mail: Neil.Richtand@uc.edu

Received 25 July 2006; revised 7 November 2006; accepted 9 November 2006
}

antipsychotic medications. These changes may influence the relationships identified in earlier analyses.

First, Civelli et al, in cloning the $\mathrm{DA}_{2}$ receptor (Bunzow et al, 1988) provided the foundation for identifying a family of three receptor subtypes, termed DA $\mathrm{D}_{2}, \mathrm{D}_{3}$ (Sokoloff et al, 1990), and $\mathrm{D}_{4}$ receptors (Van Tol et al, 1991). Together, these receptor subtypes constituted the receptor-binding affinities measured in earlier studies (Seeman et al, 1976; Creese et al, 1976). Each of these individual receptor subtypes has, in turn, been cloned, and binding data for antipsychotic drugs to these individual cloned DA receptor subtypes and their splice variants, which was not available in 1976, can now be consulted. Variability in antipsychotic medication binding to individual $\mathrm{D}_{2}$ family receptor subtypes (ie $\mathrm{D}_{2}, \mathrm{D}_{3}$, and $\mathrm{D}_{4}$ ) could help to elucidate the contribution of individual DA receptor subtypes in psychosis.

Secondly, many second-generation antipsychotic medications, which were not available in the 1970s, can now be similarly studied. Only one atypical antipsychotic medication, clozapine, had been released at the time of the original analyses in 1976. Further adding to the rationale for re- 
evaluating the relationship between DA receptor binding and antipsychotic effect is the degree to which $\mathrm{D}_{2}$ family (Kapur and Remington, 2001) compared with serotonergic (5-HT) receptor binding (Meltzer, 1999) may contribute to the antipsychotic properties of atypical antipsychotic medications.

Third, commonly prescribed doses of antipsychotic medications have changed dramatically over the past 25 years (Baldessarini et al, 1993; Vuckovic et al, 1990). Although there are few dose-finding studies adequately powered to clearly identify minimally effective antipsychotic drug dose (Zimbroff et al, 1997), currently available data (Geddes et al, 2000; Bollini et al, 1994), as well as revisions in clinical practice, have led to a marked reduction in the average prescribed doses of most typical $D_{2}$ receptor antagonists since 1976.

Fourth, cloning and pharmacological characterization of multiple serotonin receptor subtypes, including the $5-\mathrm{HT}_{1 \mathrm{~A}}$ (Fargin et al, 1988), 5- $\mathrm{HT}_{2 \mathrm{~A}}$ (Pritchett et al, 1988), and $5-\mathrm{HT}_{2 \mathrm{C}}$ (Julius et al, 1988) serotonin receptor, provide an opportunity to examine the relationship between antipsychotic binding affinities to these serotonin receptor subtypes and clinically effective antipsychotic drug dosages, an analysis not possible in 1976.

Finally, several frequently prescribed antipsychotic medications, including loxapine and perphenazine, were omitted from the original Seeman analysis, whereas an antidepressant medication (trazodone) was included (Seeman et al, 1976). It is therefore of interest to re-examine the correlation between average antipsychotic drug dosages used in the treatment of psychosis and DA and serotonin receptor subtype binding, including all commonly prescribed antipsychotic medications.

\section{METHODS}

In order to minimize variability in assay conditions that may lead to differences in $K_{\mathrm{i}}$ value for a given receptor (Strange, 2001), drug affinity $K_{\mathrm{i}}$ values determined by the NIMH Psychoactive Drug Screening Program (Roth et al, 2004) were used in our analysis. $K_{\mathrm{i}}$ values selected for analysis were those listed as NIMH Psychoactive Drug Screening Program assay certified data, determined from assays using the cloned human receptors with drugs of interest as test ligands. For $K_{\mathrm{i}}$ values for which PDSP certified assay data were not listed, the average $K_{\mathrm{i}}$ value from assay data compiled on the PDSP web site (Roth et al, 2004) using the cloned human receptor with drug of interest as the test ligand was utilized. $K_{\mathrm{i}}$ values from cloned human receptor for three drug/receptor combinations not listed in the PDSP database were identified from published literature. $K_{\mathrm{i}}$ values used in our analysis, with data source, are listed in Tables 1 and 2. As noted, all of the binding data analyzed in our study has been previously reported by other investigators.

Average daily antipsychotic drug dose was determined from data in randomized, controlled clinical trials wherever possible (Leucht et al, 1999), supplemented by the consensus clinical experience of three psychiatrists (NMR, PEK, SMS) who regularly prescribe these medications. The drug dosage ranges determined by consensus clinical experience are similar in each case to recommended dosage ranges for published drug reference guides, including ePocrates Rx (ePocrates, San Carlos, California); the Physicians' Desk Reference (Kaplan et al, 1994; Bernstein, 1988). The midpoint of the dose range was used in subsequent calculations. Values for antipsychotic drug dose were established before any data analysis, blind to specific $K_{\mathrm{i}}$ values, and are listed in Tables 1 and 2 .

\section{Data Analysis}

Antipsychotic doses and binding affinities were log-transformed before analysis. Linear regression was used to estimate the association between these quantities. A binary variable indicating antipsychotic class (typical or atypical) was also entered into the model and allowed to interact with (log) dose, so that a different regression equation could be estimated for each antipsychotic class. A test of whether the interaction term was statistically different from zero was then used to determine if separate regression equations were indicated for each antipsychotic class. A statistically significant interaction would allow rejecting the possibility that the relationship between binding and effective dosage was the same for both antipsychotic classes. It should be noted, however, that the statistical power of these tests to detect cases where class-specific relationships exist may be low, because of the limited number of data points. Consequently, failure to detect a statistical difference between the bestfitting regressions for each antipsychotic class should not be taken as proof that such a difference does not exist.

Data were analyzed using separate univariate analyses for each receptor subtype. It was not feasible to analyze data using multivariate methods because the limited number of drugs for which $K_{\mathrm{i}}$ values were available for all receptor subtypes examined did not allow for a meaningful statistical analysis.

The linear correlation coefficient $(r)$ is reported as a standardized measure of strength of association for the regressions within each class and, in cases where equality of the regressions could not be statistically rejected, for an additional regression based on combining data from both classes.

\section{RESULTS}

The correlation between average clinically effective antipsychotic dose and binding affinity to the cloned human $\mathrm{D}_{2}$ receptor is illustrated in Table 3 and Figure 1. Clinically effective dose and binding affinity to $D_{2}$ DA receptor were directly correlated for typical antipsychotic medications $(r=0.54, p=0.046)$, but not for second-generation antipsychotic medications $(r=0.41, p=0.311)$. In testing for a difference between the relationships for first- and secondgeneration drugs, an equality of regression parameters could not be statistically rejected (interaction $p=0.72$ ). Combining typical and atypical medications into a single analysis resulted in a linear correlation with $r=0.48$, $p=0.023$.

The relationship between average clinically effective dose and binding affinity to the cloned human $\mathrm{D}_{3}$ receptor is also shown in Table 3. There are no clear correlations between these variables for typical $(r=0.33, p=0.292)$ or atypical 
Table I Antipsychotic Medication Dopamine Receptor $K_{i}$ Values

\begin{tabular}{|c|c|c|c|c|c|c|c|c|c|c|}
\hline \multirow[b]{2}{*}{ Drug } & \multirow{2}{*}{$\begin{array}{l}\text { Clininically } \\
\text { effective } \\
\text { dose (mg) }\end{array}$} & \multicolumn{9}{|c|}{$K_{\mathrm{i}}$ Values $(\mathrm{nM})$} \\
\hline & & $\mathbf{D}_{\mathbf{I}}$ & $\mathbf{D}_{2}$ & $D_{2}$ short & $D_{2}$ long & $\mathbf{D}_{3}$ & $\mathbf{D}_{4}$ & $\mathrm{D}_{4.2}$ & $\mathrm{D}_{4.4}$ & $D_{5}$ \\
\hline Aripiprazole & $5-30$ & 387 & 0.95 & & 0.74 & 4.5 & $>1000$ & & & 1676 \\
\hline Benperidol & $12-16$ & & 0.027 & & & & 0.066 & & & \\
\hline Clozapine & 300-900 & 189 & 431 & 143.3 & 196 & 646 & 22.5 & 45.2 & 30 & 235 \\
\hline Fluphenazine & $2-15$ & 24 & 0.54 & & & 3 & 35 & & & 12 \\
\hline Haloperidol & $2-15$ & 83 & 2 & 1.21 & 2.34 & 12 & 3.88 & 6.93 & 15 & 147 \\
\hline Loxapine & $25-100$ & 54 & 10 & & 22.3 & 30 & 10.9 & 14 & 5.9 & 75 \\
\hline Mesoridazine & $100-400$ & & 4.3 & & & 2.6 & 9.1 & & & \\
\hline Pimozide & $2-10$ & $>10000$ & 2.51 & & & 2.84 & 1.8 & & & \\
\hline Quetiapine & $250-800$ & 712 & 567 & 555 & 702 & 483 & 2276 & 1233 & & 1738 \\
\hline Remoxipride & $200-400$ & & 243 & & 125 & 1109 & 2527 & & & \\
\hline Risperidone & $2-8$ & 60.6 & 4.9 & 4.73 & 6.0 & 12.2 & 7.12 & 16.7 & 26.3 & 16 \\
\hline Sertindole & $12-24$ & & 4.14 & 5.8 & 4.87 & 5.76 & 9.29 & 17.67 & & \\
\hline Thioridazine & $200-800$ & 89 & 10 & 8.6 & & 53 & 10.65 & & & 216 \\
\hline Thiothixene & $5-30$ & 51 & 1.4 & & & 185 & 6.4 & 548 & & 261 \\
\hline Trifluoperazine & $5-30$ & & 1.12 & & & 0.45 & 38 & 178 & & \\
\hline Ziprasidone & $80-160$ & 30 & 4.0 & 4.2 & 4.6 & 17 & 500.8 & 35.3 & & 152 \\
\hline
\end{tabular}

Normal font $=$ PDSP certified data.

Italic font $=$ PDSP $K_{i}$ database mean

Italic underlined $=($ Schoemaker et al, 1997).

Italic bold = (Seeman and Tallerico, 1998).

antipsychotic medications $(r=0.42, p=0.287)$ analyzed separately. Combining typical and atypical medications into a single analysis yielded a similar degree of correlation $(r=0.37, p=0.100)$.

The relationship between average clinically effective antipsychotic dose and binding affinity to the cloned human $\mathrm{D}_{4}$ receptor is shown in Table 3. For typical antipsychotic drugs, there was no correlation between these two measures $(r=0.24, p=0.390)$. In contrast, for atypical antipsychotics the two measures were more moderately correlated $(r=0.59, p=0.123)$. Equality of regression parameters could not be statistically rejected, however, in testing for a difference between the relationship for firstand second-generation drugs (interaction $p=0.30$ ). Combining typical and atypical medications into a single analysis did not demonstrate a significant correlation between the two variables $(r=0.37, p=0.088)$.

The relationship between average clinically effective antipsychotic dose and binding affinity to the cloned human $5-\mathrm{HT}_{1 \mathrm{~A}}$ receptor is shown in Table 3. There were no detectable direct relationships between clinically effective antipsychotic dose and receptor-binding affinity for typical $(r=0.14, \quad p=0.684)$ or atypical antipsychotic medications $(r=-0.14, p=0.791)$.
The relationship between average clinically effective antipsychotic dose and binding affinity to the cloned human $5-\mathrm{HT}_{2 \mathrm{~A}}$ receptor is shown in Table 3 and Figure 2. There is no direct relationship between clinically effective antipsychotic dose and receptor-binding affinity for typical antipsychotic medications $(r<-0.10, p=0.812)$. In contrast, for atypical antipsychotic medications binding affinity and clinically effective dose were nonsignificantly correlated, with a moderate effect size $(r=0.62$, $p=0.133)$. In testing for a difference between these two relationships, the equality of these regression parameters could not be rejected (interaction $p=0.14$ ). Combining typical and atypical medications into a single analysis eliminated the correlation between the two measures $(r=0.17, p=0.514)$.

The relationship between average clinically effective dose and binding affinity to the cloned human $5-\mathrm{HT}_{2 \mathrm{C}}$ receptor is shown in Table 3 and Figure 3. For typical antipsychotic drugs, binding affinity and clinically effective dose were surprisingly negatively correlated $(r=-0.68, p=0.021$, Figure 3a). For atypical antipsychotic medications, the direction of the correlation was opposite (Figure 3b), and there was no significant direct relationship between clinically effective antipsychotic dose and binding affinity 
Table 2 Antipsychotic Medication Serotonin Receptor $K_{i}$ Values

\begin{tabular}{|c|c|c|c|c|c|c|c|c|c|c|c|c|c|}
\hline \multirow[b]{2}{*}{ Drug } & \multirow{2}{*}{$\begin{array}{l}\text { Clininically } \\
\text { effective } \\
\text { dose (mg) }\end{array}$} & \multicolumn{12}{|c|}{$K_{\mathrm{i}}$ Values $(\mathrm{nM})$} \\
\hline & & $5-\mathrm{HT}_{1 \mathrm{~A}}$ & $5-\mathrm{HT}_{1 B}$ & $5-H T_{I D}$ & $5-\mathrm{HT}_{\mathrm{IE}}$ & $5-\mathrm{HT}_{\mathrm{IF}}$ & $5-\mathrm{HT}_{2 \mathrm{~A}}$ & $5-\mathrm{HT}_{2 B}$ & $5-\mathrm{HT}_{2 \mathrm{C}}$ & $5-\mathrm{HT}_{3}$ & $5-\mathrm{HTS}_{\mathrm{A}}$ & $5-\mathrm{HT}_{6}$ & $5-\mathrm{HT}_{7}$ \\
\hline Chlorpromazine & $300-900$ & 3115 & 1489 & 452 & 344 & & 3.32 & & 15.55 & 977 & 118 & 12 & 21 \\
\hline Chlorprothixene & $50-400$ & & & & & & 0.43 & & & & & & \\
\hline Haloperidol & $2-15$ & 1202 & 165 & 7606 & $>10000$ & $>5000$ & 118.6 & 1204 & 5580 & $>10000$ & 2247 & 3666 & 378 \\
\hline Loxapine & $25-100$ & 2456 & 388 & 3468 & 1399 & & 4.38 & & 13.3 & 190 & 776 & 33 & 88 \\
\hline Mesoridazine & $100-400$ & & & & & & & & 157 & & & 380 & \\
\hline Molindone & $20-100$ & 3797 & & & & & 4653 & & 10000 & & & 1008 & 3053 \\
\hline Olanzapine & $10-20$ & 2063 & 509 & 1582 & 2408 & 310 & 4.90 & 11.8 & 14.2 & 202 & 1212 & 6.0 & 105 \\
\hline Remoxipride & $200-400$ & & & & & & 6225 & & & & & & \\
\hline Risperidone & $2-8$ & 427 & 53.6 & 29.2 & $>10000$ & 1240 & 0.481 & 41.6 & 33.4 & $>10000$ & 205.8 & 2241 & 6.6 \\
\hline Sertindole & $12-24$ & 280 & 60 & 96 & 430 & 360 & 0.387 & & 0.9 & & & 5.4 & 28 \\
\hline Thioridazine & $200-800$ & 108 & 109 & 579 & 194 & & 21.5 & & 53 & $>10000$ & 364 & 57 & 99 \\
\hline Thiothixene & $5-30$ & 410 & $|5|$ & 659 & $>10000$ & & 50 & & 1356 & 1863 & 361 & 208 & 15 \\
\hline Trifluoperazine & $5-30$ & 950 & & & & & 74 & & 378 & & & 144 & 291 \\
\hline Ziprasidone & $80-160$ & 76 & 4 & 9 & 1279 & & 0.73 & & 13 & $>10000$ & 291 & 61 & 6 \\
\hline
\end{tabular}

Normal font $=$ PDSP certified data.

Italic font $=$ PDSP $K_{i}$ database mean.

Table 3 Correlation Between Clinically Effective Antipsychotic Dose and Receptor Binding Affinity

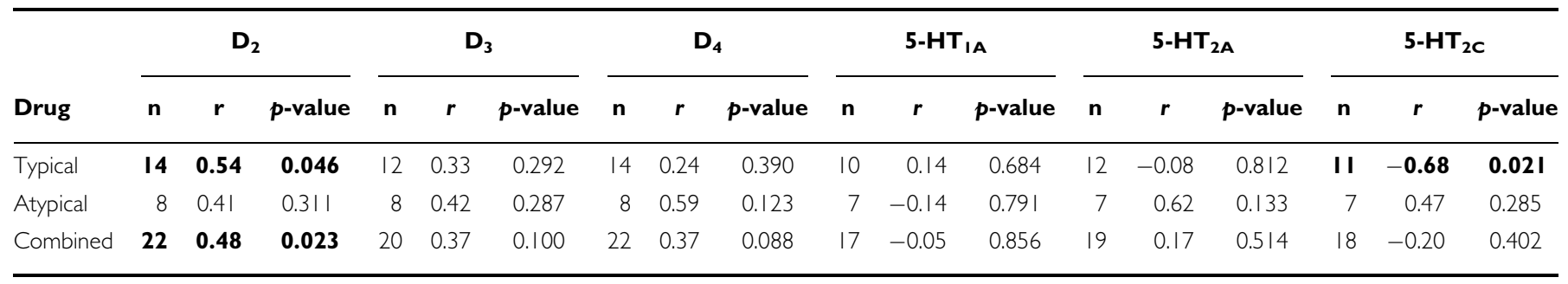

Bold font indicates $p$-value $<0.05$.

$(r=0.47, p=0.285)$. In testing for a difference between these two relationships, the regression parameters were significantly different (interaction $p=0.020$ ). As would be expected, combining typical and atypical medications into a single analysis eliminated any correlation between clinically effective dose and $5-\mathrm{HT}_{2 \mathrm{C}}$ receptor binding $(r=-0.20$, $p=0.40$ ).

In order to evaluate possible interactions between receptor subtypes playing a role in mechanism of antipsychotic efficacy, we analyzed correlations between log (average dose) and log (ratio of binding affinities) for combinations of individual receptor subtypes, as shown in Table 4. As illustrated in Figure $4 \mathrm{a}$, there is a modest negative correlation between average clinically effective dose and ratio of binding affinities for $5-\mathrm{HT}_{2 \mathrm{~A}} / \mathrm{D}_{2}$ receptors for typical antipsychotic medication $(r=-0.52, p=0.082)$, however, surprisingly for atypical antipsychotics, there was no detectable relationship between dose and $5-\mathrm{HT}_{2 \mathrm{~A}} / \mathrm{D}_{2}$ binding affinity ratio $(r=-0.08, p=0.869$, Figure $4 b)$.

As shown in Figure 5a, typical antipsychotic medication dose and $5-\mathrm{HT}_{2 \mathrm{C}} / \mathrm{D}_{2}$ receptor-binding affinity ratios were strongly and inversely correlated $(r=-0.81, p=0.003)$. In contrast, there was no detectable relationship between dose and $5-\mathrm{HT}_{2 \mathrm{C}} / \mathrm{D}_{2}$ receptor-binding affinity ratio for secondgeneration antipsychotic medications $(r=-0.30, p=0.507$, Figure $5 c$ ).

A similar analysis of $5-\mathrm{HT}_{2 \mathrm{~A}} / \mathrm{D}_{3}$ receptor-binding affinity ratios did not identify correlations between these values and clinically effective dosages of typical $(r=-0.40, p=0.216)$ or atypical $(r<0.01, p=0.997)$, or pooled first- and secondgeneration antipsychotic medications, as illustrated in Table 4. 

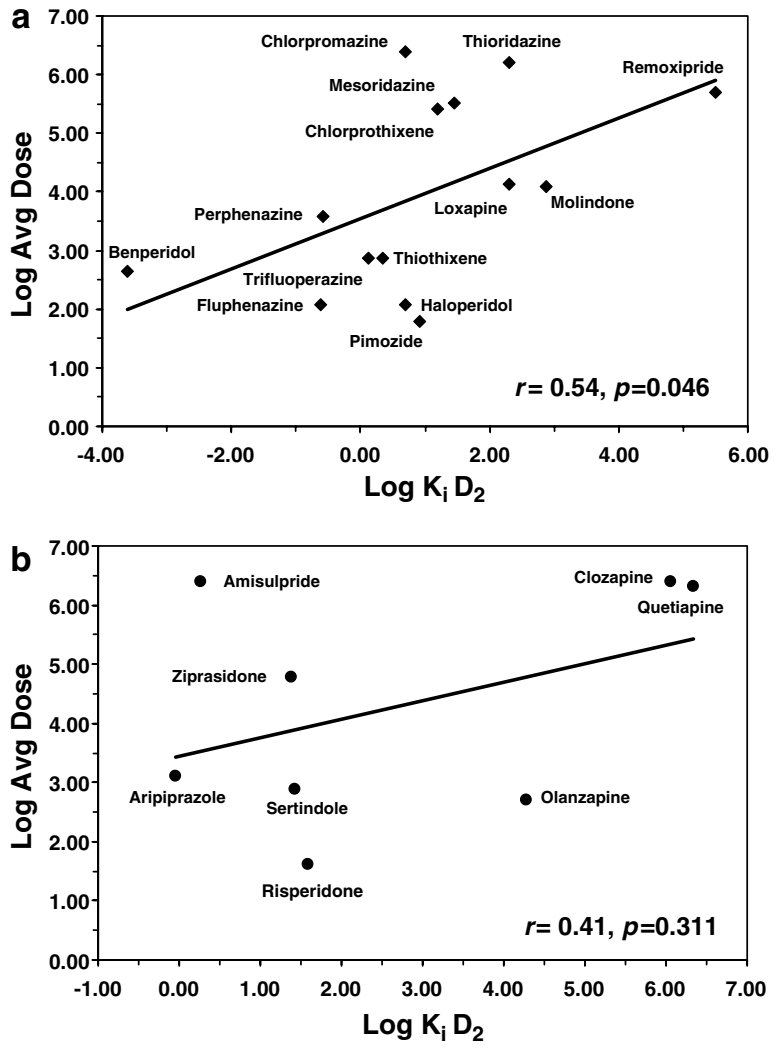

Figure I Clinically effective antipsychotic dose vs binding affinity to cloned human DA $D_{2}$ receptor for (a) typical and (b) atypical antipsychotic medications.

In contrast, $5-\mathrm{HT}_{2 \mathrm{C}} / \mathrm{D}_{3}$ receptor-binding affinity ratios were correlated with clinically effective dosages of typical antipsychotic medications $(r=-0.67, p=0.023$, Figure 6a). $5-\mathrm{HT}_{2 \mathrm{C}} / \mathrm{D}_{4}$ receptor-binding affinity ratios were similarly correlated with clinically effective dosages of typical antipsychotic medications $(r=-0.70, p=0.016$, Figure $7 \mathrm{a})$. A comparable relationship, however, was not observed for atypical antipsychotic medications, as $5-\mathrm{HT}_{2 \mathrm{C}} / \mathrm{D}_{3}$ (Figure $6 \mathrm{~b}$ ) and $5-\mathrm{HT}_{2 \mathrm{C}} / \mathrm{D}_{4}$ (Figure $7 \mathrm{~b}$ ) receptor-binding affinity ratios were not correlated with clinically effective dosages of atypical antipsychotic medications.

Analysis of DA and serotonin receptor-binding affinities singly and in simple combinations did not identify correlations between receptor subtype binding and clinical efficacy for atypical antipsychotic medications. We therefore further evaluated the relationship between receptor binding and efficacy using a more comprehensive set of binding affinity ratios. Although there is not a universal consensus on this point, it has previously been suggested that the antipsychotic effect of atypical antipsychotic medications results from a balance of inhibition at serotonin $5-\mathrm{HT}_{2 \mathrm{~A}}, 5-\mathrm{HT}_{2 \mathrm{C}}$, and $\mathrm{DA} \mathrm{D}_{2}$ receptors (Meltzer, 1989; Meltzer, 1995; Leysen et al, 1993; Huttunen, 1995), coupled with simultaneous agonist effects at serotonin 5$\mathrm{HT}_{1 \mathrm{~A}}$ receptors (Meltzer, 1999; Millan, 2000; Protais et al, 1994). In order to identify therapeutic benefit resulting from the interaction between simultaneous effects at these receptor subtypes, we determined the relationship between
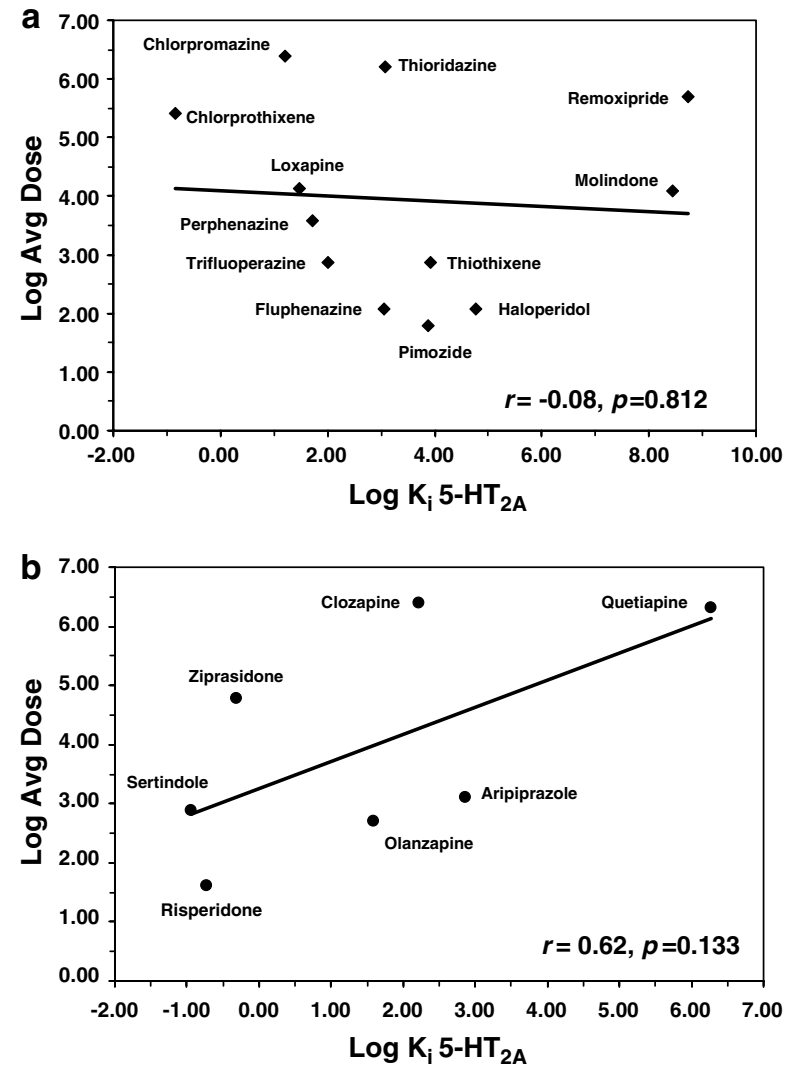

Figure 2 Clinically effective antipsychotic dose vs binding affinity to cloned human serotonin 5- $\mathrm{HT}_{2 \mathrm{~A}}$ receptor for (a) typical and (b) atypical antipsychotic medications.

clinically effective antipsychotic medication dose and ratios incorporating the binding affinities for each of these receptor systems. As shown in Table 4 and Figure 8 (lower panel), atypical antipsychotic medication dose and $\mathrm{D}_{2}$ (5$\left.\mathrm{HT}_{2 \mathrm{~A}} / 5-\mathrm{HT}_{1 \mathrm{~A}}\right)$ binding affinity ratio are highly correlated $(r=0.80, p=0.031)$. Similarly, $\mathrm{D}_{2}\left(5-\mathrm{HT}_{2 \mathrm{C}} / 5-\mathrm{HT}_{1 \mathrm{~A}}\right)$ binding affinity ratio and atypical antipsychotic medication dose are also highly correlated $(r=0.78, p=0.038$, Figure 9 , lower panel). In contrast, neither binding affinity ratio is significantly correlated with clinically effective dose for typical antipsychotic medications (Figures 8 and 9, upper panels). Removing the $5-\mathrm{HT}_{1 \mathrm{~A}}$ receptor-binding affinity term from the equation by correlating antipsychotic medication dose with $\left(5-\mathrm{HT}_{2 \mathrm{~A}} \times \mathrm{D}_{2}\right)$ or $\left(5-\mathrm{HT}_{2 \mathrm{C}} \times \mathrm{D}_{2}\right)$ binding affinity ratio lessens the resulting degree of correlation (Table 4). Similarly, the receptor-binding relationships can be modified, so that $5-\mathrm{HT}_{1 \mathrm{~A}}$ and $\mathrm{D}_{2}$ receptor binding no longer have functionally opposite roles, and $\mathrm{D}_{2}$ binding no longer has a functionally similar action as $5-\mathrm{HT}_{2 \mathrm{~A}}$ and $5-\mathrm{HT}_{2 \mathrm{C}}$ binding, by inverting the serotonin receptor affinity terms (Table 4, lower right two columns). This modification completely eliminates the correlation between binding affinity ratio and drug dosage for atypical antipsychotic medications. Typical antipsychotic drug dosage, in contrast, is significantly correlated with the resulting binding affinity ratio $\mathrm{D}_{2}\left(5-\mathrm{HT}_{1 \mathrm{~A}} / 5-\mathrm{HT}_{2 \mathrm{C}}\right)$ $(r=0.75, p=0.013)$. Comparing this result to the $5-\mathrm{HT}_{2 \mathrm{C}} /$ $\mathrm{D}_{2}$ binding affinity $v s$ typical antipsychotic drug dosage 

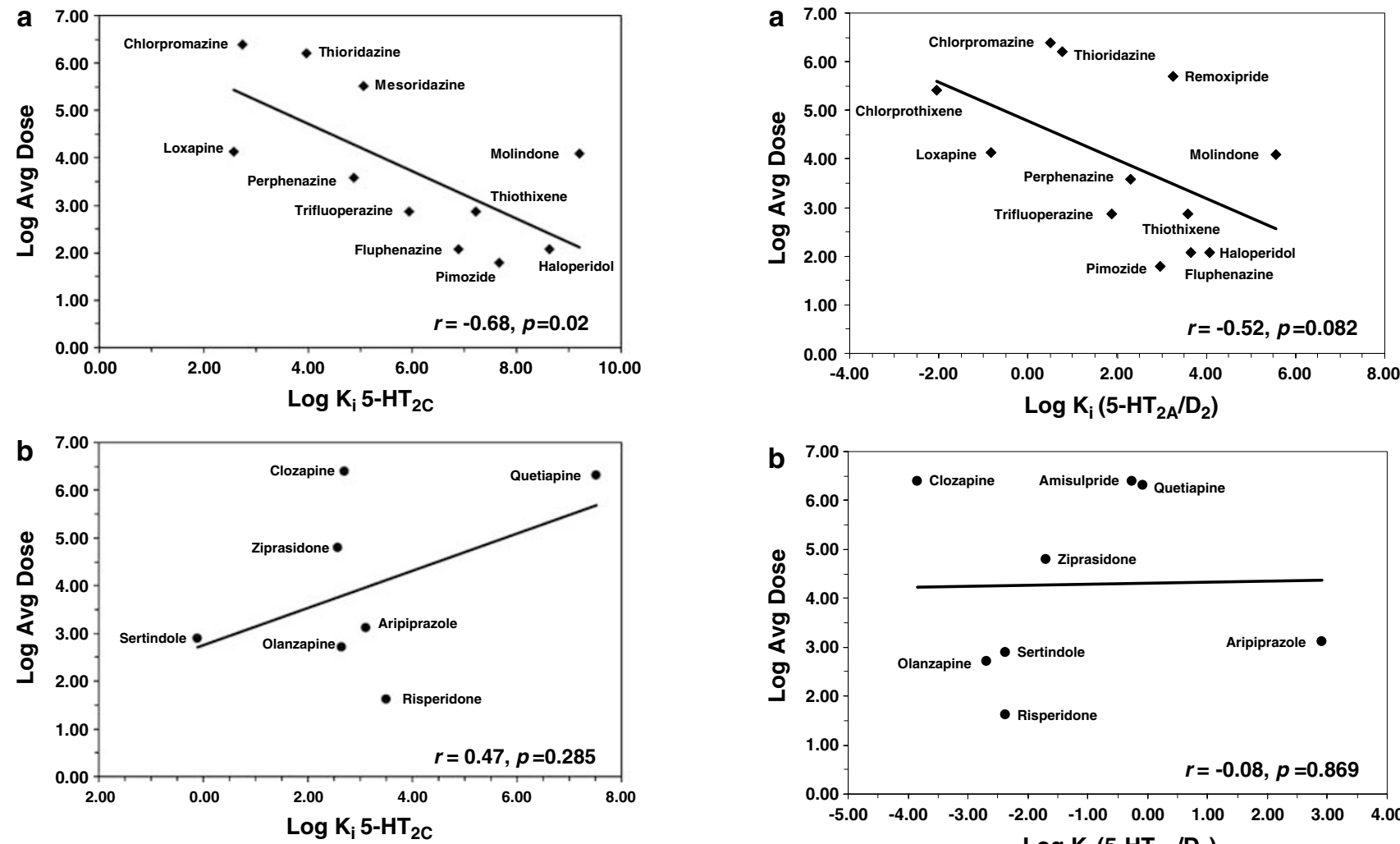

Figure 3 Clinically effective antipsychotic dose vs binding affinity to cloned human serotonin $5-\mathrm{HT}_{2 \mathrm{C}}$ receptor for (a) typical and (b) atypical antipsychotic medications.

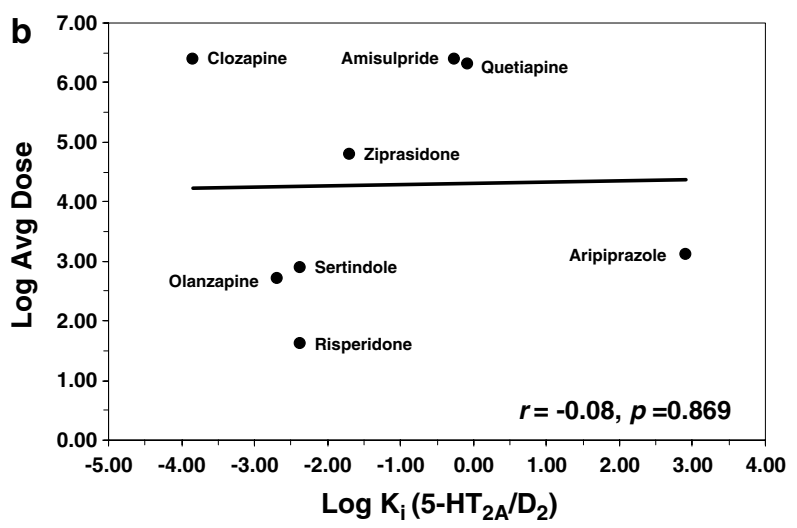

Figure 4 Clinically effective antipsychotic dose vs ratio of binding affinity to cloned human serotonin $5-\mathrm{HT}_{2 \mathrm{~A}} / \mathrm{DA} \mathrm{D}_{2}$ receptor for (a) typical and (b) atypical antipsychotic medications.

Table 4 Correlation Between Clinically Effective Antipsychotic Dose and Receptor Binding Affinity Ratios

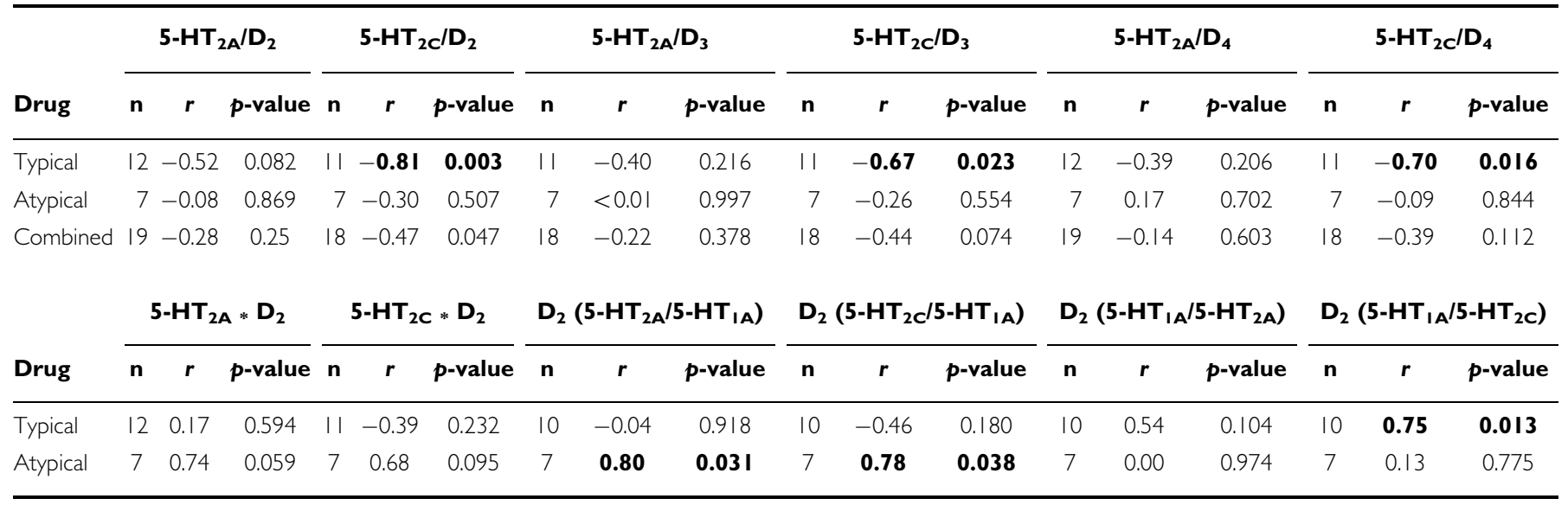

Bold font indicates $p$-value $<0.05$.

correlation described above (Table 4) suggests that the $\mathrm{D}_{2} / 5-\mathrm{HT}_{2 \mathrm{C}}$ term contributes the majority of influence to this relationship.

\section{DISCUSSION}

Here, we present data evaluating the relationship between binding affinity to several catecholamine receptor subtypes and drug dosage for antipsychotic efficacy. Our analysis is similar in concept to prior studies demonstrating a linear correlation between antipsychotic drug dose and $\mathrm{D}_{2}$-family DA receptor-binding affinity (Seeman et al, 1976; Creese et al, 1976). Our goal was to evaluate additional DA and serotonin receptor subtypes, which had not been identified at the time of the earlier analyses, in order to determine whether affinity to individual receptor subtypes could be correlated with antipsychotic potency of these medications. 

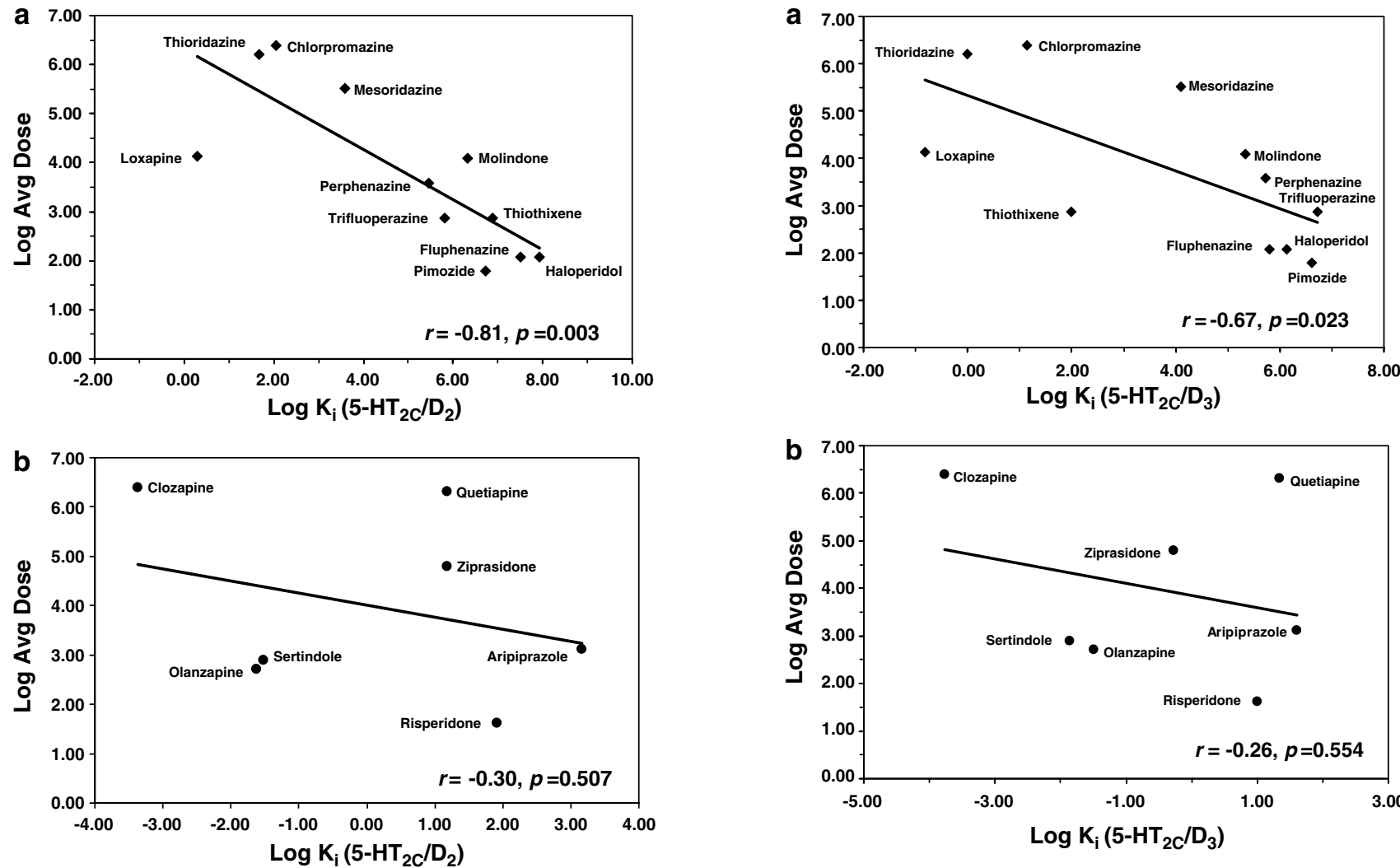

Figure 5 Clinically effective antipsychotic dose vs ratio of binding affinity to cloned human serotonin $5-H_{2}$ C/DA $D_{2}$ receptor for (a) typical and (b) atypical antipsychotic medications.

Although we expected to identify common DA receptor subtypes mediating antipsychotic efficacy for both typical and atypical antipsychotic medications, our analysis instead identified surprising differences in serotonergic mechanisms mediating antipsychotic efficacy for typical $v s$ atypical medications. The major findings identified by analysis of this data are discussed below.

\section{Typical Antipsychotic Medications}

In agreement with earlier studies, we determined that antipsychotic drug dosage for typical antipsychotic medications is directly correlated with binding to $\mathrm{D}_{2} \mathrm{DA}$ receptors, however, the strength of this correlation was less robust than anticipated. Our data suggest that this may be related in part to interactions between typical antipsychotic medications and serotonin $5-\mathrm{HT}_{2 \mathrm{C}}$ receptors. The observation that serotonin $5-\mathrm{HT}_{2 \mathrm{C}}$ receptor affinity is negatively correlated with antipsychotic drug dosage for typical antipsychotic medications was an unexpected outcome of our data analysis. Additionally, $5-\mathrm{HT}_{2 \mathrm{C}}$ and $\mathrm{D}_{2}$ receptorbinding affinities of typical antipsychotic medications interact such that the ratio of serotonin $5-\mathrm{HT}_{2 \mathrm{C}} / \mathrm{D}_{2}$ receptor-binding affinity more accurately predicts dosage needed for antipsychotic effect than do $5-\mathrm{HT}_{2 \mathrm{C}}$ or $\mathrm{D}_{2}$ binding affinities independently. Thus, increasing serotonin $5-\mathrm{HT}_{2 \mathrm{C}}$ receptor antagonist affinity lowers antipsychotic potency at any given level of $\mathrm{D}_{2}$ blockade, suggesting that signaling through $5-\mathrm{HT}_{2 \mathrm{C}}$ receptors interacts with and

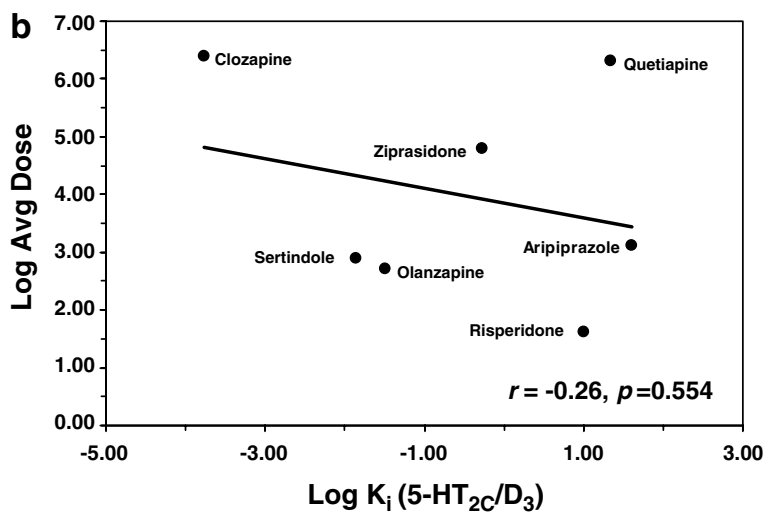

Figure 6 Clinically effective antipsychotic dose vs ratio of binding affinity to cloned human serotonin $5-\mathrm{HT}_{2} \mathrm{C} / \mathrm{DA} \mathrm{D}_{3}$ receptor for (a) typical and (b) atypical antipsychotic medications.

improves antipsychotic effects achieved via $D_{2}$ receptor blockade. In contrast, the correlation between serotonin 5$\mathrm{HT}_{2 \mathrm{C}}$ receptor affinity and clinically effective antipsychotic drug dose for atypical antipsychotic medications differs from the correlation for typical medications $(p=0.02)$, is in the opposite direction, and the degree of correlation is less pronounced (Figure 3). Although a potential role for $5-\mathrm{HT}_{2 \mathrm{C}}$ receptor antagonism in the therapeutic effect of atypical antipsychotic medications has previously been discussed (Meltzer et al, 2003; Meltzer, 1995; Wood et al, 2006), it has also been suggested that $5-\mathrm{HT}_{2 \mathrm{C}}$ agonism could be therapeutic (Meltzer, 1999; Marquis et al, 2007) based on a wide range of preclinical measures demonstrating that serotonin $5-\mathrm{HT}_{2 \mathrm{C}}$ receptor stimulation inhibits the mesolimbic DA system (Alex et al, 2005; Pozzi et al, 2002; Di Giovanni et al, 1999; De Deurwaerdere and Spampinato, 1999; Millan et al, 1998; Di Matteo et al, 1999; Di Matteo et al, 2002). These findings are consistent with our observation, and suggest a potential mechanism for 5$\mathrm{HT}_{2 \mathrm{C}}$ receptor blockade to worsen psychotic symptoms. Human data supporting the concept that $5-\mathrm{HT}_{2 \mathrm{C}}$ blockade lowers the antipsychotic potency of first-generation antipsychotic medications has not been previously elucidated to our knowledge, however.

The neuroanatomical mechanism(s) underlying this finding may be related to the tonic inhibitory control exerted by serotonin operating through $5-\mathrm{HT}_{2 \mathrm{C}}$ receptors over limbic dopaminergic pathways (De Deurwaerdere and Spampinato, 1999). Serotonergic cell bodies originating in 

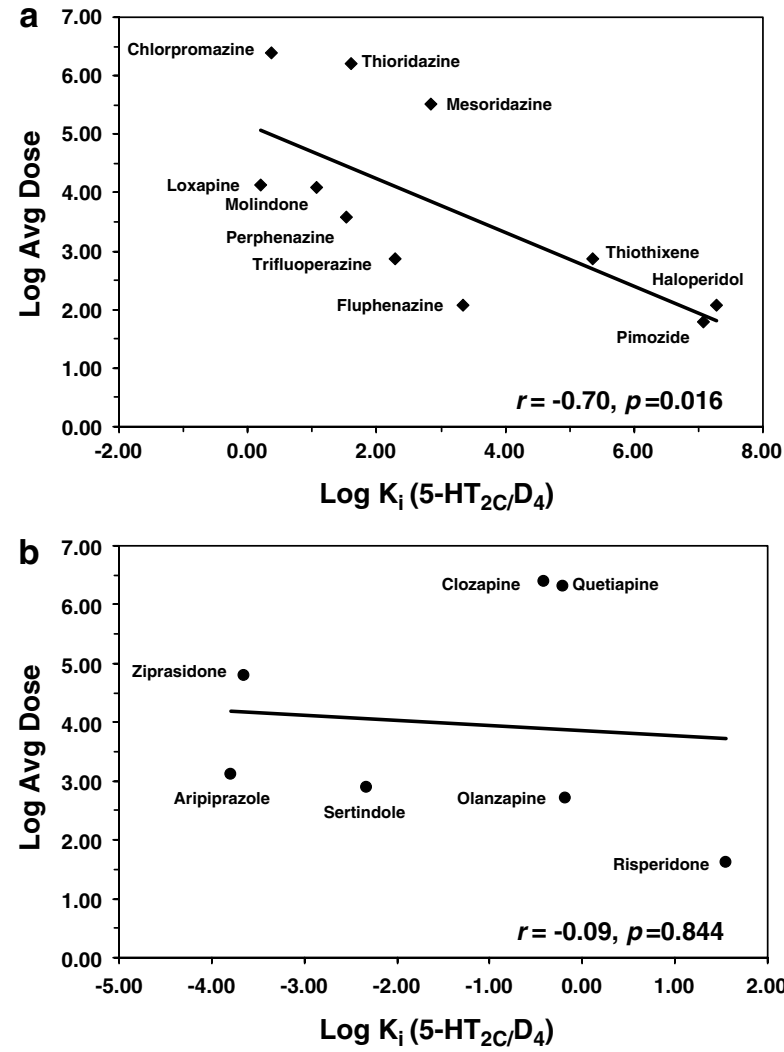

Figure 7 Clinically effective antipsychotic dose vs ratio of binding affinity to cloned human serotonin $5-\mathrm{HT}_{2} \mathrm{C} / \mathrm{DA} \mathrm{D}_{4}$ receptor for (a) typical and (b) atypical antipsychotic medications.

the raphe nucleus project diffusely to targets throughout the brain, and strong $5-\mathrm{HT}_{2 \mathrm{C}}$ receptor expression has been observed in nucleus accumbens and ventral striatum, with modest expression in prefrontal cortex (LopezGimenez et al, 2001; Eberle-Wang et al, 1997). In prefrontal cortex, 5- $\mathrm{HT}_{2 \mathrm{C}}$ receptors are co-expressed with $\mathrm{DA} \mathrm{D}_{4}$ receptors (Vysokanov et al, 1998). Within the substantia nigra/ventral tegmentum, $5-\mathrm{HT}_{2 \mathrm{C}}$ receptors are expressed on inhibitory GABA-ergic interneurons (Eberle-Wang et al, 1997). 5- $\mathrm{HT}_{2 \mathrm{C}}$ receptor stimulation inhibits reward system-related behaviors including cocaine-induced hyperlocomotion (Filip and Cunningham, 2003; Grottick et al, 2000). $5-\mathrm{HT}_{2 \mathrm{C}}$ receptor blockade increases both dopaminergic cell firing and DA release in nucleus accumbens and frontal cortex (Alex et al, 2005; Di Matteo et al, 1999; Millan et al, 1998). 5- $\mathrm{HT}_{2 \mathrm{C}}$ receptor blockade could oppose the actions of $\mathrm{D}_{2} \mathrm{DA}$ receptor blockade either through direct effects on second messenger systems in neurons co-expressing $\mathrm{DA} \mathrm{D}_{2}$ and $5-\mathrm{HT}_{2 \mathrm{C}}$ receptors, or indirectly through a systems effect on components of limbic neurotransmission. In addition to antagonist effects through inhibition of basal serotonin tone, constitutive activity of $5-\mathrm{HT}_{2 \mathrm{C}}$ receptor isoforms have also been previously described (Niswender et al, 1999; Westphal et al, 1995), and this constitutive activity participates in the tonic inhibition of mesolimbic DA function (De Deurwaerdere et al, 2004). Antipsychotic medications could therefore also function as inverse agonists through second messenger pathways of $5-\mathrm{HT}_{2 \mathrm{C}}$ isoforms (Navailles
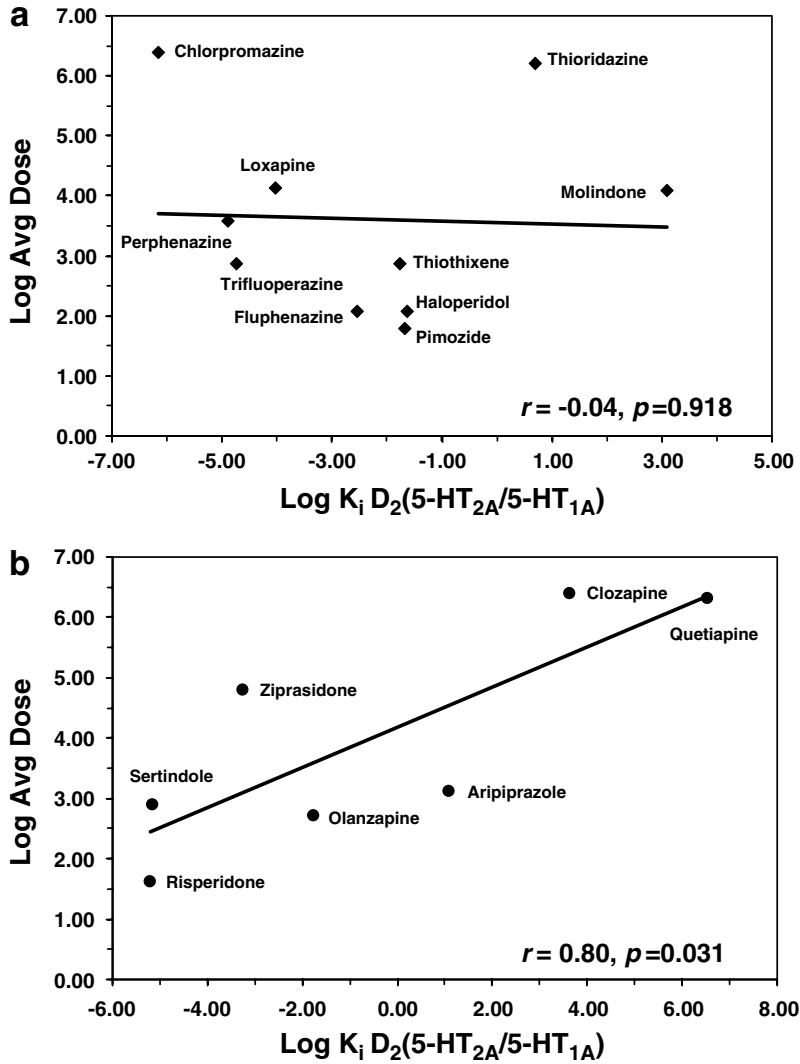

Figure 8 Clinically effective antipsychotic dose vs ratio of binding affinity to cloned human $\mathrm{D}_{2}\left(5-\mathrm{HT}_{2 \mathrm{~A}} / 5-\mathrm{HT}_{1 \mathrm{~A}}\right)$ receptor for (a) typical and (b) atypical antipsychotic medications.

et al, 2006; Rauser et al, 2001). Although previous studies of the $5-\mathrm{HT}_{2 \mathrm{C}}$ inverse agonist properties of antipsychotic medications have identified the potential role for inverse agonism in the mechanism of action of antipsychotic efficacy (Navailles et al, 2006), our data suggest an alternative possibility that $5-\mathrm{HT}_{2 \mathrm{C}}$ inverse agonism may also directly oppose acute antipsychotic efficacy. Our analysis supports the concept that $5-\mathrm{HT}_{2 \mathrm{C}}$ agonists, in contrast, may have therapeutic potential as adjunctive medications to improve antipsychotic efficacy for patients receiving typical antipsychotic medication, and suggests that these medications could have applications for treatment refractory psychosis. The potential therapeutic benefit of $5-\mathrm{HT}_{2 \mathrm{C}}$ stimulation in inhibiting psychotic symptoms through inhibition of meso-accumbens DA function must be balanced with the potential for worsening of cognitive and negative symptoms through decreased mesocortical DA function.

$5-\mathrm{HT}_{2 \mathrm{C}} / \mathrm{D}_{3}$ and to a lesser extent $5-\mathrm{HT}_{2 \mathrm{C}} / \mathrm{D}_{4}$ binding affinity ratios were also correlated with clinically effective antipsychotic medication dose for typical antipsychotic medications. Our data therefore suggest the likelihood of an interaction between binding at serotonin $5-\mathrm{HT}_{2 \mathrm{C}}$ and $\mathrm{DA}$ $D_{2}, D_{3}$, and $D_{4}$ receptors in the mechanism of action of typical antipsychotic medications.

Our analysis identifies a modest correlation between antipsychotic drug dosage and the ratio of serotonin 5$\mathrm{HT}_{2 \mathrm{~A}} / \mathrm{D}_{2}$ receptor affinity for typical antipsychotic medications. 

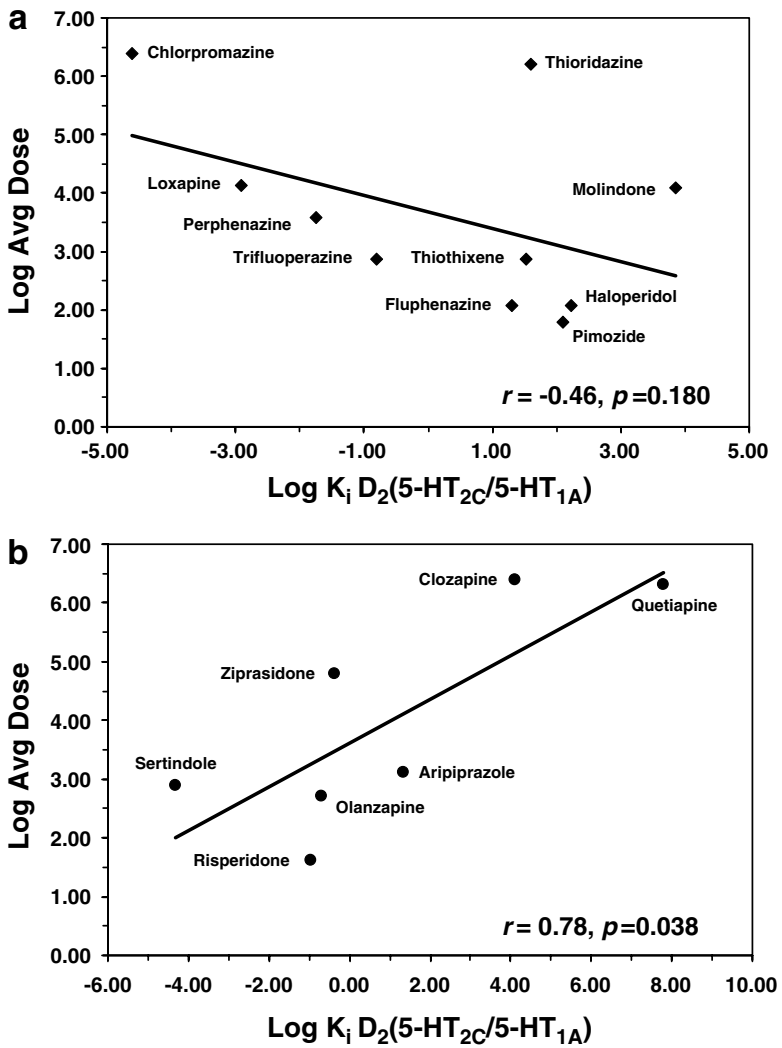

Figure 9 Clinically effective antipsychotic dose vs ratio of binding affinity to cloned human $\mathrm{D}_{2}\left(5-\mathrm{HT}_{2} \mathrm{~d} / \mathrm{H}-\mathrm{HT} \mathrm{T}_{\mathrm{A}}\right)$ receptor for (a) typical and (b) atypical antipsychotic medications.

\section{Atypical Antipsychotic Medications}

Therapeutic efficacy for atypical antipsychotic medications has been suggested to result from a balance of inhibition at DA $\mathrm{D}_{2}$, serotonin $5-\mathrm{HT}_{2 \mathrm{~A}}$, and $5-\mathrm{HT}_{2 \mathrm{C}}$ receptors (Meltzer, 1989, 1995; Leysen et al, 1993; Huttunen, 1995), whereas serotonin $5-\mathrm{HT}_{1 \mathrm{~A}}$ receptor stimulation appears to contribute to antipsychotic efficacy in rat models (Protais et al, 1994; Meltzer et al, 2003; Millan, 2000). Consistent with these observations, clinically effective dosages of atypical antipsychotic medication are highly correlated with the ratios of $\mathrm{D}_{2}\left(5-\mathrm{HT}_{2 \mathrm{~A}} / 5-\mathrm{HT}_{1 \mathrm{~A}}\right)$ and $\mathrm{D}_{2}\left(5-\mathrm{HT}_{2 \mathrm{C}} / 5-\mathrm{HT}_{1 \mathrm{~A}}\right)$ receptor-binding affinities. Thus, our analysis suggests that the therapeutic effects of atypical antipsychotic medications are determined by interactions among three different domains: (1) increasing $\mathrm{D}_{2}$ DA receptor-binding affinity enhances antipsychotic potency. (2) Increasing $5-\mathrm{HT}_{2 \mathrm{C}}$ and $5-\mathrm{HT}_{2 \mathrm{~A}}$ receptor-binding affinities also facilitate antipsychotic efficacy. (3) Increasing $5-\mathrm{HT}_{1 \mathrm{~A}}$ receptor-binding affinity, in contrast, reduces antipsychotic efficacy.

We are not aware of other studies demonstrating that serotonin $5-\mathrm{HT}_{2 \mathrm{C}}$ receptor blockade has opposite effects in typical and atypical antipsychotic medications. It has previously been suggested, however, that both $5-\mathrm{HT}_{2 \mathrm{C}}$ antagonism (Meltzer et al, 2003; Meltzer, 1995; Wood et al, 2006) and 5- $\mathrm{HT}_{2 \mathrm{C}}$ receptor stimulation (Meltzer, 1999; Marquis et al, 2007) could facilitate antipsychotic activity. Our data support the view that this seemingly paradoxical finding may result from the relatively higher $5-\mathrm{HT}_{2 \mathrm{~A}}$ receptor blockade in atypical $v s$ typical medications. Thus, simultaneous $5-\mathrm{HT}_{2 \mathrm{~A}}$ and $5-\mathrm{HT}_{2 \mathrm{C}}$ receptor blockade may be more effective in mediating antipsychotic effects than blockade of either receptor separately (Meltzer et al, 2003).

Our finding that a simple linear correlation between $\mathrm{D}_{2}$ receptor binding and clinically effective drug dosage is not apparent for atypical antipsychotic drugs was an unexpected outcome. Previous studies have determined that atypical antipsychotic medications can be distinguished from typical antipsychotic drugs based on the ratio of 5$\mathrm{HT}_{2} / \mathrm{D}_{2}$-binding affinities (Meltzer et al, 1989a, b). Thus, we had anticipated a more direct relationship between $D_{2}$ binding and antipsychotic efficacy for second-generation medications, and an interaction between serotonin $5-\mathrm{HT}_{2 \mathrm{~A}}$ and $\mathrm{D}_{2}$ effects. Instead, we observed a modest correlation between atypical antipsychotic drug dosage and serotonin $5-\mathrm{HT}_{2 \mathrm{~A}}$ receptor binding, and a similarly modest correlation between DA $\mathrm{D}_{4}$ receptor-binding affinity and atypical antipsychotic drug dosages. It has previously been suggested that a subset of atypical antipsychotic medications derive their efficacy in part from selective effects at $\mathrm{D}_{4} \mathrm{DA}$ receptors (Seeman et al, 1997). Our data do not provide evidence supporting the concept that a simple ratio of binding to $5-\mathrm{HT}_{2 \mathrm{~A}}$ and $\mathrm{D}_{2}$ receptors accounts for a significant proportion of atypical antipsychotic medication efficacy, although this ratio does appears to distinguish between atypical and typical medication classes (Meltzer et al, 1989a, b). Addition of more members of the atypical class to the relatively small number of drugs available for our analysis might help to further clarify this issue.

\section{Limitations}

Our analysis is limited to antipsychotic medication effects on positive psychotic symptoms, and does not address efficacy for negative symptoms or cognition, which may be more important in terms of long-term functional outcome. Importantly, the strength of correlations between receptor binding and antipsychotic efficacy identified in our analysis are restricted by a wide range of limiting factors. Medication differences in absorption; metabolism; protein binding; and the presence of pharmacologically active metabolites all serve to weaken the observed correlations. Additionally, the antipsychotic medication dose prescribed to patients may be determined in part by side effects, and might therefore not accurately reflect the 'ideal' efficacy dose. The paucity of adequately powered clinical trials to determine optimal dose for antipsychotic medications further limits the accuracy of medication dosages employed in our analysis. Also, the binding data used in the current analysis, measuring ligand binding to cloned human receptors expressed in cell culture systems, may be distinct from binding to limbic neurotransmitter receptor populations in vivo. Differences in receptor phosphorylation, glycosylation, and/or dimerization to hetero-oligomers (Nimchinsky et al, 1997; Scarselli et al, 2001; Zawarynski et al, 1998; Lee et al, 2000) between in vivo and cell culture systems lacking post-translational machinery could potentially alter receptor-binding affinity. Additionally, atypical antipsychotic medications as a group tend to have more rapid dissociation rates from DA receptors than typical antipsychotics (Kapur and Seeman, 2001), an effect that might further complicate the relationship between receptor affinity and clinically effective drug 
dose. And finally, this approach is inherently limited by the complexities of brain circuitry in which DA and serotonin receptors may function as a 'brake' in one brain region, and simultaneously as an 'accelerator' in a different brain region. For example, blockade of $\mathrm{D}_{2} \mathrm{DA}$ autoreceptors in cell body regions of the ventral tegmentum increases both synthesis and release of DA, which could worsen psychotic symptoms, whereas blockade of postsynaptic $D_{2}$ receptors in limbic terminal regions would likely have an opposite behavioral effect. Thus, the dysfunction of schizophrenia, resulting from a complex interaction of multiple receptor and neurotransmitter systems (Carlsson et al, 1999), does not lend itself ideally to an analysis of isolated receptor systems.

In summary, we present data demonstrating correlations between clinical efficacies of antipsychotic medications and binding affinities to $\mathrm{D}_{2}, \mathrm{D}_{3}, \mathrm{D}_{4}, 5-\mathrm{HT}_{1 \mathrm{~A}}, 5-\mathrm{HT}_{2 \mathrm{~A}}$, and $5-\mathrm{HT}_{2 \mathrm{C}}$ receptor subtypes. Given the numerous limitations inherent in this approach (listed above), the strength of correlations described in this analysis suggest that the DA and serotonin receptor subtypes analyzed provide the preponderance of antipsychotic effect of these medications. The specific mechanism(s) underlying this clinical effect, however, remains obscure. The 'disconnect' between the pharmacokinetics of receptor blockade and the extended time lag until clinical benefit suggests antipsychotic efficacy, while initiated through binding to neurotransmitter receptor target(s), is likely the result of a downstream cascade of changes in gene transcription and translation. Studies identifying the specific targets of altered gene transcription resulting from these drug-neurotransmitter receptor interactions would therefore have high likelihood of improving specificity and efficacy of antipsychotic medications.

\section{ACKNOWLEDGEMENTS}

This work was supported by the Department of Veterans Affairs Medical Research Service, and by a NARSAD Essel Investigator Award (NMR).

\section{STATEMENT OF INTERESTS}

The authors disclose the following relationships, which might potentially bias this work:

Neil M Richtand: Grant support: Janssen, AstraZeneca

Speaker's bureaus: Bristol-Myers Squibb, Pfizer, and Otsuka America Pharmaceutical.

Consultant: Solvay Pharmaceuticals

Stephen M Strakowski: Grant support: Eli Lilly, Janssen,

Pfizer, Forrest, AstraZeneca, Bristol-Myers Squibb

Consultant: OrthoMcNeil, Pfizer

Speaker's bureaus: Eli Lilly, Janssen, Pfizer, Forrest, AstraZeneca, Bristol-Myers Squibb, OrthoMcNeil

Paul E Keck Jr: Grant support: principal or co-investigator on research studies sponsored by: Abbott Laboratories, the American Diabetes Association, AstraZeneca, Bristol-Myers Squibb, GlaxoSmithKline, Eli Lilly, Janssen Pharmaceutica, Memory Pharmaceuticals, Merck, National Institute of Mental Health (NIMH), National Institute of
Drug Abuse (NIDA), Organon, Ortho-McNeil, Pfizer, the Stanley Medical Research Institute (SMRI), and UCB Pharma.

Dr Keck is a consultant to, or member of the scientific advisory boards of: Abbott Laboratories, AstraZeneca Pharmaceuticals, Bristol-Myers Squibb, GlaxoSmithKline, Janssen Pharmceutica, Eli Lilly and Company, Memory Pharmaceuticals, Neurocrine Biosciences, Ortho-McNeil, Pfizer, and Shire.

\section{REFERENCES}

Alex KD, Yavanian GJ, McFarlane HG, Pluto CP, Pehek EA (2005). Modulation of dopamine release by striatal 5-HT2C receptors. Synapse 55: 242-251.

Baldessarini RJ, Cohen BM, Teicher MH (1993). Clinical dosing of neuroleptics. Psychopharmacol Ser 10: 138-148.

Bernstein JG (1988). Handbook of Drug Therapy in Psychiatry. PSG Publishing Company, Inc.: Littleton, MA.

Bollini P, Pampallona S, Orza MJ, Adams ME, Chalmers TC (1994). Antipsychotic drugs: is more worse? A meta-analysis of the published randomized control trials. Psychol Med 24: 307-316.

Bunzow JR, Van Tol HH, Grandy DK, Albert P, Salon J, Christie M et al (1988). Cloning and expression of a rat D2 dopamine receptor cDNA. Nature 336: 783-787.

Carlsson A, Waters N, Carlsson ML (1999). Neurotransmitter interactions in schizophrenia-therapeutic implications. Eur Arch Psychiatry Clin Neurosci 249(Suppl 4): 37-43.

Creese I, Burt DR, Snyder SH (1976). Dopamine receptor binding predicts clinical and pharmacological potencies of antischizophrenic drugs. Science 192: 481-483.

De Deurwaerdere P, Navailles S, Berg KA, Clarke WP, Spampinato $\mathrm{U}$ (2004). Constitutive activity of the serotonin2C receptor inhibits in vivo dopamine release in the rat striatum and nucleus accumbens. J Neurosci 24: 3235-3241.

De Deurwaerdere P, Spampinato U (1999). Role of serotonin(2A) and serotonin $(2 \mathrm{~B} / 2 \mathrm{C})$ receptor subtypes in the control of accumbal and striatal dopamine release elicited in vivo by dorsal raphe nucleus electrical stimulation. J Neurochem 73: 1033-1042.

Di Giovanni G, De Deurwaerdere P, Di Mascio M, Di Matteo V, Esposito E, Spampinato U (1999). Selective blockade of serotonin-2C/2B receptors enhances mesolimbic and mesostriatal dopaminergic function: a combined in vivo electrophysiological and microdialysis study. Neuroscience 91: 587-597.

Di Matteo V, Cacchio M, Di Giulio C, Esposito E (2002). Role of serotonin(2C) receptors in the control of brain dopaminergic function. Pharmacol Biochem Behav 71: 727-734.

Di Matteo V, Di Giovanni G, Di Mascio M, Esposito E (1999). SB 242084 , a selective serotonin2C receptor antagonist, increases dopaminergic transmission in the mesolimbic system. Neuropharmacology 38: 1195-1205.

Eberle-Wang K, Mikeladze Z, Uryu K, Chesselet MF (1997). Pattern of expression of the serotonin2 $\mathrm{C}$ receptor messenger RNA in the basal ganglia of adult rats. J Comp Neurol 384: 233-247.

Emilien G, Maloteaux JM, Geurts M, Hoogenberg K, Cragg S (1999). Dopamine receptors - physiological understanding to therapeutic intervention potential. Pharmacol Ther 84: 133-156.

Fargin A, Raymond JR, Lohse MJ, Kobilka BK, Caron MG, Lefkowitz RJ (1988). The genomic clone G-21 which resembles a beta-adrenergic receptor sequence encodes the 5-HT1A receptor. Nature 335: 358-360.

Filip M, Cunningham KA (2003). Hyperlocomotive and discriminative stimulus effects of cocaine are under the control of serotonin(2C) $(5-\mathrm{HT}(2 \mathrm{C}))$ receptors in rat prefrontal cortex. J Pharmacol Exp Ther 306: 734-743. 
Geddes J, Freemantle N, Harrison P, Bebbington P (2000). Atypical antipsychotics in the treatment of schizophrenia: systematic overview and meta-regression analysis. BMJ 321: 1371-1376.

Grottick AJ, Fletcher PJ, Higgins GA (2000). Studies to investigate the role of 5-HT(2C) receptors on cocaine- and food-maintained behavior. J Pharmacol Exp Ther 295: 1183-1191.

Huttunen M (1995). The evolution of the serotonin-dopamine antagonist concept. J Clin Psychopharmacol 15: 4S-10S.

Julius D, MacDermott AB, Axel R, Jessell TM (1988). Molecular characterization of a functional cDNA encoding the serotonin $1 \mathrm{c}$ receptor. Science 241: 558-564.

Kaplan HI, Sadock BJ, Grebb JA (1994). Dopamine receptor antagonists (antipsychotics). In: Cancro R, Gabbard GO, Jones RM, Kaplan PM, Pataki CS, Sadock VA (eds). Synopsis of Psychiatry. Williams and Wilkins: Philadelphia. pp 940-960.

Kapur S, Remington G (2001). Dopamine D(2) receptors and their role in atypical antipsychotic action: still necessary and may even be sufficient. Biol Psychiatry 50: 873-883.

Kapur S, Seeman P (2001). Does fast dissociation from the dopamine $\mathrm{d}(2)$ receptor explain the action of atypical antipsychotics? A new hypothesis. Am J Psychiatry 158: 360-369.

Lee SP, O’Dowd BF, Ng GY, Varghese G, Akil H, Mansour A et al (2000). Inhibition of cell surface expression by mutant receptors demonstrates that $\mathrm{D} 2$ dopamine receptors exist as oligomers in the cell. Mol Pharmacol 58: 120-128.

Leucht S, Pitschel-Walz G, Abraham D, Kissling W (1999). Efficacy and extrapyramidal side-effects of the new antipsychotics olanzapine, quetiapine, risperidone, and sertindole compared to conventional antipsychotics and placebo. A meta-analysis of randomized controlled trials. Schizophr Res 35: 51-68.

Leysen JE, Janssen PM, Schotte A, Luyten WH, Megens AA (1993). Interaction of antipsychotic drugs with neurotransmitter receptor sites in vitro and in vivo in relation to pharmacological and clinical effects: role of 5HT2 receptors. Psychopharmacology (Berlin) 112: S40-S54.

Lopez-Gimenez JF, Mengod G, Palacios JM, Vilaro MT (2001). Regional distribution and cellular localization of 5-HT2C receptor mRNA in monkey brain: comparison with mesulergine binding sites and choline acetyltransferase mRNA. Synapse 42: $12-26$.

Marquis KL, Sabb AL, Logue SF, Brennan JA, Piesla MJ, Comery TA et al (2007). WAY-163909 ((7bR,10aR)-1,2,3,4,8,9,10,10aoctahydro-7bH-cyclopenta-[b]diazepino[6,7,1hi]indole): a novel 5-HT2C receptor selective agonist with preclinical antipsychoticlike activity. J Pharmacol Exp Ther 320: 486-496.

Meltzer HY (1989). Clinical studies on the mechanism of action of clozapine: the dopamine-serotonin hypothesis of schizophrenia. Psychopharmacology (Berlin) 99(Suppl): S18-S27.

Meltzer HY (1995). The role of serotonin in schizophrenia and the place of serotonin-dopamine antagonist antipsychotics. J Clin Psychopharmacol 15: 2S-3S.

Meltzer HY (1999). The role of serotonin in antipsychotic drug action. Neuropsychopharmacology 21: 106S-115S.

Meltzer HY, Li Z, Kaneda Y, Ichikawa J (2003). Serotonin receptors: their key role in drugs to treat schizophrenia. Prog Neuropsychopharmacol Biol Psychiatry 27: 1159-1172.

Meltzer HY, Matsubara S, Lee JC (1989a). Classification of typical and atypical antipsychotic drugs on the basis of dopamine D-1, D-2 and serotonin2 pKi values. J Pharmacol Exp Ther 251: 238246.

Meltzer HY, Matsubara S, Lee JC (1989b). The ratios of serotonin2 and dopamine2 affinities differentiate atypical and typical antipsychotic drugs. Psychopharmacol Bull 25: 390-392.

Millan MJ (2000). Improving the treatment of schizophrenia: focus on serotonin (5-HT)(1A) receptors. J Pharmacol Exp Ther 295: 853-861.

Millan MJ, Dekeyne A, Gobert A (1998). Serotonin (5-HT)2C receptors tonically inhibit dopamine (DA) and noradrenaline
(NA), but not 5-HT, release in the frontal cortex in vivo. Neuropharmacology 37: 953-955.

Navailles S, De Deurwaerdere P, Spampinato U (2006). Clozapine and haloperidol differentially alter the constitutive activity of central serotonin2C receptors in vivo. Biol Psychiatry 59: 568-575.

Nimchinsky EA, Hof PR, Janssen WGM, Morrison JH, Schmauss C (1997). Expression of dopamine D3 receptor dimers and tetramers in brain and in transfected cells. J Biol Chem 272: 29229-29237.

Niswender CM, Copeland SC, Herrick-Davis K, Emeson RB, Sanders-Bush E (1999). RNA editing of the human serotonin 5-hydroxytryptamine $2 \mathrm{C}$ receptor silences constitutive activity. $J$ Biol Chem 274: 9472-9478.

Pozzi L, Acconcia S, Ceglia I, Invernizzi RW, Samanin R (2002). Stimulation of 5-hydroxytryptamine (5-HT(2C)) receptors in the ventrotegmental area inhibits stress-induced but not basal dopamine release in the rat prefrontal cortex. J Neurochem 82: 93-100.

Pritchett DB, Bach AW, Wozny M, Taleb O, Dal Toso R, Shih JC et al (1988). Structure and functional expression of cloned rat serotonin 5HT-2 receptor. EMBO J 7: 4135-4140.

Protais P, Chagraoui A, Arbaoui J, Mocaer E (1994). Dopamine receptor antagonist properties of $S$ 14506, 8-OH-DPAT, raclopride and clozapine in rodents. Eur J Pharmacol 271: 167-177.

Rauser L, Savage JE, Meltzer HY, Roth BL (2001). Inverse agonist actions of typical and atypical antipsychotic drugs at the human 5-hydroxytryptamine(2C) receptor. J Pharmacol Exp Ther 299: 83-89.

Roth BL, Lopez E, Beischel S, Westkaemper RB, Evans JM (2004). Screening the receptorome to discover the molecular targets for plant-derived psychoactive compounds: a novel approach for CNS drug discovery. Pharmacol Ther 102: 99-110.

Scarselli M, Novi F, Schallmach E, Lin R, Baragli A, Colzi A et al (2001). D2/D3 dopamine receptor heterodimers exhibit unique functional properties. J Biol Chem 276: 30308-30314.

Schoemaker H, Claustre Y, Fage D, Rouquier L, Chergui K, Curet O et al (1997). Neurochemical characteristics of amisulpride, an atypical dopamine D2/D3 receptor antagonist with both presynaptic and limbic selectivity. J Pharmacol Exp Ther 280: 83-97.

Seeman P (2002). Atypical antipsychotics: mechanism of action. Can J Psychiatry 47: 27-38.

Seeman P, Corbett R, Van Tol HH (1997). Atypical neuroleptics have low affinity for dopamine D2 receptors or are selective for D4 receptors. Neuropsychopharmacology 16: 93-110.

Seeman P, Lee T, Chau-Wong M, Wong K (1976). Antipsychotic drug doses and neuroleptic/dopamine receptors. Nature 261: 717-719.

Seeman P, Tallerico T (1998). Antipsychotic drugs which elicit little or no parkinsonism bind more loosely than dopamine to brain D2 receptors, yet occupy high levels of these receptors. Mol Psychiatry 3: 123-134.

Sokoloff P, Giros B, Martres MP, Bouthenet ML, Schwartz JC (1990). Molecular cloning and characterization of a novel dopamine receptor (D3) as a target for neuroleptics. Nature 347: $146-151$.

Strange PG (2001). Antipsychotic drugs: importance of dopamine receptors for mechanisms of therapeutic actions and side effects. Pharmacol Rev 53: 119-133.

Van Tol HH, Bunzow JR, Guan HC, Sunahara RK, Seeman P, Niznik HB et al (1991). Cloning of the gene for a human dopamine D4 receptor with high affinity for the antipsychotic clozapine. Nature 350: 610-614.

Vuckovic A, Cohen BM, Keck PEJ, Shedlack KJ (1990). Neuroleptic dosage regimens in psychotic inpatients: a retrospective comparison. J Clin Psychiatry 51: 107-109. 
Vysokanov A, Flores-Hernandez J, Surmeier DJ (1998). mRNAs for clozapine-sensitive receptors co-localize in rat prefrontal cortex neurons. Neurosci Lett 258: 179-182.

Westphal RS, Backstrom JR, Sanders-Bush E (1995). Increased basal phosphorylation of the constitutively active serotonin $2 \mathrm{C}$ receptor accompanies agonist-mediated desensitization. $\mathrm{Mol}$ Pharmacol 48: 200-205.

Wood MD, Scott C, Clarke K, Cato KJ, Patel N, Heath J et al (2006). Pharmacological profile of antipsychotics at monoamine recep-

tors: atypicality beyond 5-HT2A receptor blockade. CNS Neurol Disord Drug Targets 5: 445-452.

Zawarynski P, Tallerico T, Seeman P, Lee SP, O'Dowd BF, George SR (1998). Dopamine D2 receptor dimers in human and rat brain. FEBS Lett 441: 383-386.

Zimbroff DL, Kane JM, Tamminga CA, Daniel DG, Mack RJ, Wozniak PJ et al (1997). Controlled, dose-response study of sertindole and haloperidol in the treatment of schizophrenia. Sertindole Study Group. Am J Psychiatry 154: 782-791. 